\title{
Serological detection of infection with canine distemper virus, canine parvovirus and canine adenovirus in communal dogs from Zimbabwe
}

\begin{tabular}{|c|c|}
\hline \multicolumn{2}{|l|}{ Authors: } \\
\hline \multicolumn{2}{|c|}{ Rebecca P. Wilkes ${ }^{1}$} \\
\hline \multicolumn{2}{|c|}{ Jessica Dawson² } \\
\hline \multicolumn{2}{|c|}{ Roger Parry ${ }^{2}$} \\
\hline \multicolumn{2}{|l|}{ Chris Foggin ${ }^{2}$} \\
\hline \multicolumn{2}{|l|}{ Hayley Adams ${ }^{3}$} \\
\hline \multicolumn{2}{|c|}{ Agricola Odoi ${ }^{1}$} \\
\hline \multicolumn{2}{|c|}{ Melissa A. Kennedy ${ }^{1}$} \\
\hline \multicolumn{2}{|l|}{ Affiliations: } \\
\hline \multicolumn{2}{|c|}{$\begin{array}{l}{ }^{1} \text { Department of Biomedical } \\
\text { and Diagnostic Sciences, } \\
\text { University of Tennessee, } \\
\text { United States }\end{array}$} \\
\hline \multicolumn{2}{|c|}{$\begin{array}{l}{ }^{2} \text { Victoria Falls Wildlife Trust, } \\
\text { Zimbabwe }\end{array}$} \\
\hline \multicolumn{2}{|c|}{$\begin{array}{l}{ }^{3} \text { Silent Heroes Foundation, } \\
\text { United States }\end{array}$} \\
\hline \multicolumn{2}{|c|}{$\begin{array}{l}\text { Correspondence to: } \\
\text { Melissa Kennedy }\end{array}$} \\
\hline \multicolumn{2}{|c|}{$\begin{array}{l}\text { Email: } \\
\text { mkenned2@utk.edu }\end{array}$} \\
\hline \multicolumn{2}{|c|}{$\begin{array}{l}2407 \text { River Drive, Knoxville, } \\
\text { Tennessee 37996, } \\
\text { United States }\end{array}$} \\
\hline \multicolumn{2}{|c|}{$\begin{array}{l}\text { Rates: } \\
\text { Received: } 19 \text { Sept. } 2013 \\
\text { Accepted: } 15 \text { Jan. } 2014 \\
\text { Published: } 05 \text { Sept. } 2014\end{array}$} \\
\hline \multicolumn{2}{|c|}{$\begin{array}{l}\text { How to cite this article: } \\
\text { McRee, A., Wilkes, R.P., } \\
\text { Dawson, J., Parry, R., Foggin, } \\
\text { C., Adams, H. et al., 2014, } \\
\text { 'Serological detection } \\
\text { of infection with canine } \\
\text { distemper virus, canine } \\
\text { parvovirus and canine } \\
\text { adenovirus in communal } \\
\text { dogs from Zimbabwe', } \\
\text { Journal of the South African } \\
\text { Veterinary Association } 85(1) \text {, } \\
\text { Art. \#1110, } 2 \text { pages. http:// } \\
\text { dx.doi.org/10.4102/jsava. } \\
\text { v85i1.1110 }\end{array}$} \\
\hline Read online: & \\
\hline 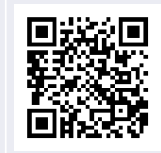 & $\begin{array}{l}\text { Scan this QR } \\
\text { code with your } \\
\text { smart phone or } \\
\text { mobile device } \\
\text { to read online. }\end{array}$ \\
\hline
\end{tabular}

Domestic dogs are common amongst communities in sub-Saharan Africa and may serve as important reservoirs for infectious agents that may cause diseases in wildlife. Two agents of concern are canine parvovirus (CPV) and canine distemper virus (CDV), which may infect and cause disease in large carnivore species such as African wild dogs and African lions, respectively. The impact of domestic dogs and their diseases on wildlife conservation is increasing in Zimbabwe, necessitating thorough assessment and implementation of control measures. In this study, domestic dogs in north-western Zimbabwe were evaluated for antibodies to CDV, CPV, and canine adenovirus (CAV). These dogs were communal and had no vaccination history. Two hundred and twenty-five blood samples were collected and tested using a commercial enzyme-linked immunosorbent assay (ELISA) for antibodies to CPV, CDV, and CAV. Of these dogs, 75 (34\%) had detectable antibodies to CDV, whilst $191(84 \%)$ had antibodies to CPV. Antibodies to canine adenovirus were present in 28 (13\%) dogs. Canine parvovirus had high prevalence in all six geographic areas tested. These results indicate that CPV is circulating widely amongst domestic dogs in the region. In addition, CDV is present at high levels. Both pathogens can infect wildlife species. Efforts for conservation of large carnivores in Zimbabwe must address the role of domestic dogs in disease transmission.

\section{Introduction}

Dogs are important members of communities throughout sub-Saharan Africa and are the most common carnivore on the continent (Alexander et al. 2010). Dogs thrive in human-dominated ecosystems, and rural villages of Zimbabwe are no exception. It is estimated that over $70 \%$ of domestic dogs in Zimbabwe reside on communal lands (Butler \& Bingham 2000; Butler, Du Toit \& Bingham 2004). The majority of dogs are free-roaming. Most receive little, if any, veterinary care and thus no vaccinations, except periodic rabies vaccination; therefore, life expectancy of these dogs is little more than one year, and over $70 \%$ of these dogs die within the first year of life, many due to infectious disease (Butler \& Bingham 2000). Nevertheless, these dogs may act as key reservoirs of infectious agents that could infect and cause disease in wildlife (Cleaveland et al. 2006). For example, continued circulation of pathogens such as canine distemper virus (CDV) and canine parvovirus (CPV) provide opportunities for virus exposure to wildlife species, as many of these dogs enter wildlife habitats. It is estimated that over $60 \%$ of Zimbabwean nature reserves adjoin communal lands (Butler \& Bingham 2000). Some of these encroachments have already led to epidemics of disease amongst wildlife, including African wild dogs and lions (Butler et al. 2004; Gordon \& Angrick 1986). The impact of domestic dogs and their diseases on wildlife conservation is increasing in Zimbabwe, necessitating thorough assessment and implementation of control measures (Butler et al. 2004).

\section{Materials and methods}

Domestic dogs in north-western Zimbabwe were evaluated for antibodies to CDV, CPV and canine adenovirus (CAV), three important and highly contagious pathogens affecting dogs and wildlife globally. Free-roaming communal dogs residing on rural communal lands in Hwange District bordering both Victoria Falls and Zambezi National Parks were used for this investigation. Sampling was done during periodic cattle dipping at established sites in the region: Chidobe, Kachechete, Donrovan, Chizuma, Breakfast and Woodland. Blood samples $(n=225)$ were collected opportunistically from domestic dogs by jugular venipuncture. Sex and approximate age were noted for each animal.

Vaccination for CDV, CPV and CAV (Merial, Atlanta, Georgia, USA) was used as incentive for participation. Serum samples were stored in polypropylene tubes at $-20{ }^{\circ} \mathrm{C}$ until testing. 
TABLE 1: Seroprevalence for selected pathogens in domestic dogs on communal lands in north-western Zimbabwe, 2012.

\begin{tabular}{|c|c|c|c|c|c|c|c|c|c|c|}
\hline \multirow[t]{2}{*}{ Region } & \multicolumn{10}{|c|}{ Pathogen prevalence ( $95 \%$ binomial exact confidence interval) } \\
\hline & Number & CDV & $\mathrm{CCP}=0.023$ & $p$-value & CPV & $\mathrm{CCP}=0.003$ & $p$-value & CAV & $\mathrm{CCP}=0.029$ & $p$-value \\
\hline Chidobe $\left(18^{\circ} 2^{\prime} \mathrm{S}, 25^{\circ} 52^{\prime} \mathrm{E}\right)$ & 26 & $11.5^{\mathrm{a}}$ & 2.4 & 30.2 & $84.6^{a}$ & 65.1 & 95.6 & $19.2^{\mathrm{a}}$ & 6.6 & 39.4 \\
\hline Kachechete $\left(18^{\circ} 5^{\prime} \mathrm{S}, 25^{\circ} 59^{\prime} \mathrm{E}\right)$ & 40 & $45.0^{\mathrm{b}}$ & 29.3 & 61.5 & $87.5^{\mathrm{a}}$ & 73.2 & 95.8 & $25.0^{\mathrm{a}}$ & 12.7 & 41.2 \\
\hline Donrovan $\left(18^{\circ} 7^{\prime} \mathrm{S}, 25^{\circ} 48^{\prime} \mathrm{E}\right)$ & 40 & $30.0^{b}$ & 16.6 & 46.5 & $82.5^{\mathrm{a}}$ & 67.2 & 92.7 & $5.0^{a, b}$ & 0.6 & 16.9 \\
\hline Chizuma ( $\left.18^{\circ} 0^{\prime} \mathrm{S}, 25^{\circ} 53^{\prime} \mathrm{E}\right)$ & 48 & $47.9^{b}$ & 33.3 & 62.8 & $81.3^{\mathrm{a}}$ & 67.4 & 91.1 & $27.1^{\mathrm{a}}$ & 15.3 & 41.8 \\
\hline Breakfast $\left(18^{\circ} 17^{\prime} \mathrm{S}, 2^{\circ} 5^{\circ} 5^{\prime} \mathrm{E}\right)$ & 30 & $6.7^{\mathrm{a}}$ & 0.0 & 22.1 & $76.7^{\mathrm{a}}$ & 57.8 & 90.1 & $0.0^{\mathrm{b}}$ & 0.0 & 11.6 \\
\hline Woodland $\left(18^{\circ} 4^{\prime} \mathrm{S}, 25^{\circ} 44^{\prime} \mathrm{E}\right)$ & 41 & $46.3^{b}$ & 30.7 & 62.6 & $92.7^{\mathrm{a}}$ & 80.1 & 98.5 & $0.0^{\mathrm{b}}$ & 0.0 & 8.6 \\
\hline All locations & 225 & $34.2^{\mathrm{b}}$ & 28.0 & 40.8 & $84.4^{\mathrm{a}}$ & 79.0 & 88.9 & $13.3^{\mathrm{a}}$ & 9.2 & 18.5 \\
\hline
\end{tabular}

CDV, canine distemper virus; CPV, canine parvovirus; CAV, canine adenovirus; CCP, collected critical.

$a$ and $b$, within a column (pathogen), estimates with different superscript letters are significantly different.

Antibodies to CDV, CPV and CAV were assessed using Biogal Titer Check, according to manufacturer directions (Biogal Galed Laboratories, Kibbutz Galed, Israel). Prevalence estimates were computed and compared across regions and the Simes method was used to adjust for multiple comparisons.

\section{Results}

Results are presented in Table 1 . The majority of dogs tested were male $(n=153 ; 68 \%)$ and young adults $(n=189 ; 84 \%)$. Of these dogs, 75 (34\%) had detectable antibodies to CDV, whilst 191 (84\%) had antibodies to CPV. Antibodies to CAV were present in $28(13 \%)$ of the dogs. Canine parvovirus had high prevalence in all six geographic areas tested. Two locales, Woodland and Breakfast, had no animals seropositive to CAV, whilst a third, Donrovan, had only one CAV-seropositive dog.

\section{Discussion}

These results indicate that CPV is widely circulating amongst domestic dogs in the region. In addition, CDV is present at high levels. Both pathogens can infect wildlife species such as African wild dogs, which are endangered, as well as other canid species, hyena and African lions. Previous studies (Prager et al. 2012) have shown that exposure to CDV amongst African wild dogs is associated with unfenced, protected and unprotected areas where contact with domestic dogs is highly probable. Canine parvovirus in particular could pose a threat due to its hardiness in the environment; direct contact is not required and the virus may remain infectious for as long as two years (Van de Bildt et al. 2002). Based on the results of this study, CAV does not appear to be as prevalent amongst the domestic dog population in Zimbabwe.

Infectious diseases pose an important threat to wildlife populations in Africa and have been responsible in part for declining numbers of some populations, such as African wild dogs (Prager et al. 2012). Agents such as CDV and CPV may be responsible for die-offs, particularly amongst pups as maternal immunity wanes. Determination of risk factors is an important step in aiding management of these populations and institution of preventive measures. These may include vaccination of resident domestic dog populations to reduce the risk of exposure to contagious canine pathogens. Vaccination of domestic dog reservoirs has been the main approach for protecting endangered carnivores in the Serengeti-Mara ecosystem of Kenya and Tanzania (Vanak, Belsare \& Gompper 2007). With a population growth rate of $>6 \%$, communal dogs of Zimbabwe pose a significant threat for ecological disruption (Butler \& Bingham 2000). Efforts for conservation of large carnivores in Zimbabwe must address the role of domestic dogs in disease transmission.

\section{Acknowledgements}

The authors would like to thank Misty Bailey (University of Tennessee, Knoxville) for editorial assistance, Merial (Duluth, Georgia, USA) for provision of canine DAP vaccines as incentives for sample collection, and Biogal (Kibbutz Galed, Israel) for provision of ELISA kits.

\section{Competing interests}

The authors declare that they have no financial or personal relationship(s) which may have inappropriately influenced them in writing this article.

\section{Authors' contributions}

A.M. (University of Tennessee) collected samples, history and data as well as performed serologic assays. R.P.W. (University of Tennessee), J.D., R.P. (Victoria Falls Wildlife Trust), C.F. (Victoria Falls Wildlife Trust) and H.A. (Silent Heroes Foundation) assisted with project design and implementation. A.O. (University of Tennessee) performed statistical analyses, and M.K. (University of Tennessee) was the project leader.

\section{References}

Alexander, K.A., McNutt, J.W., Briggs, M.B., Standers, P.E., Funston, P., Hemson, G. et al., 2010, 'Multi-host pathogens and carnivore management in southern Africa', Comparative Immunology, Microbiology, and Infectious Diseases 33(3), 249-265.

Butler, J.R.A. \& Bingham, J., 2000, 'Demography and dog-human relationships of the dog population in Zimbabwean communal lands', Veterinary Record 147(16), 442-446.

Butler, J.R.A., Du Toit, J.T. \& Bingham J., 2004, 'Free-ranging domestic dogs (Canis familiaris) as predators and prey in rural Zimbabwe: Threats of competition and disease to large wild carnivores', Biological Conservation 115(3), 369-378.

Cleaveland, S., Kaare, M., Knobel, D. \& Laurenson, M.K., 2006, 'Canine vaccination - Providing broader benefits for disease control', Veterinary Microbiology 117(1), 43-50.

Gordon, J.C. \& Angrick, E.J., 1986, 'Canine parvovirus: Environmental effects on infectivity', American Journal of Veterinary Research 47(7), 1464-1467.

Prager, K.C., Mazet, J.A.K., Munson, L., Cleaveland, S., Donnelly, C.A., Dubovi, E.J. et al., 2012, 'The effect of protected areas on pathogen exposure in endangered African wild dog (Lycaon pictus) populations', Biological Conservation 150(1), 15-22.

Vanak, A.T., Belsare, A.V. \& Gompper, M.E., 2007, Survey of disease prevalence in free-ranging domestic dogs and possible spill-over risk for wildlife: A case study from the Great Indian Bustard Sanctuary, Maharashtra State - India, Rufford Small Grants Foundation, London.

Van de Bildt, M.W., Kuiken, T., Visee, A.M., Lema, S., Fitzjohn, T.R. \& Osterhaus, A.D.M.E., 2002, 'Distemper outbreak and its effect on African wild dog conservation', Emerging Infectious Diseases 8(2), 211-213. 